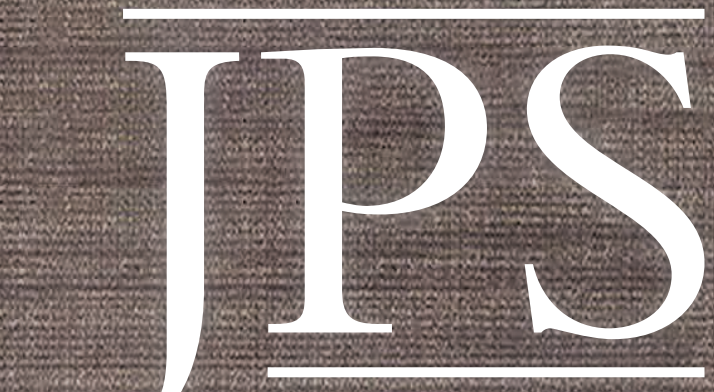

The Journal of the Polynesian Society
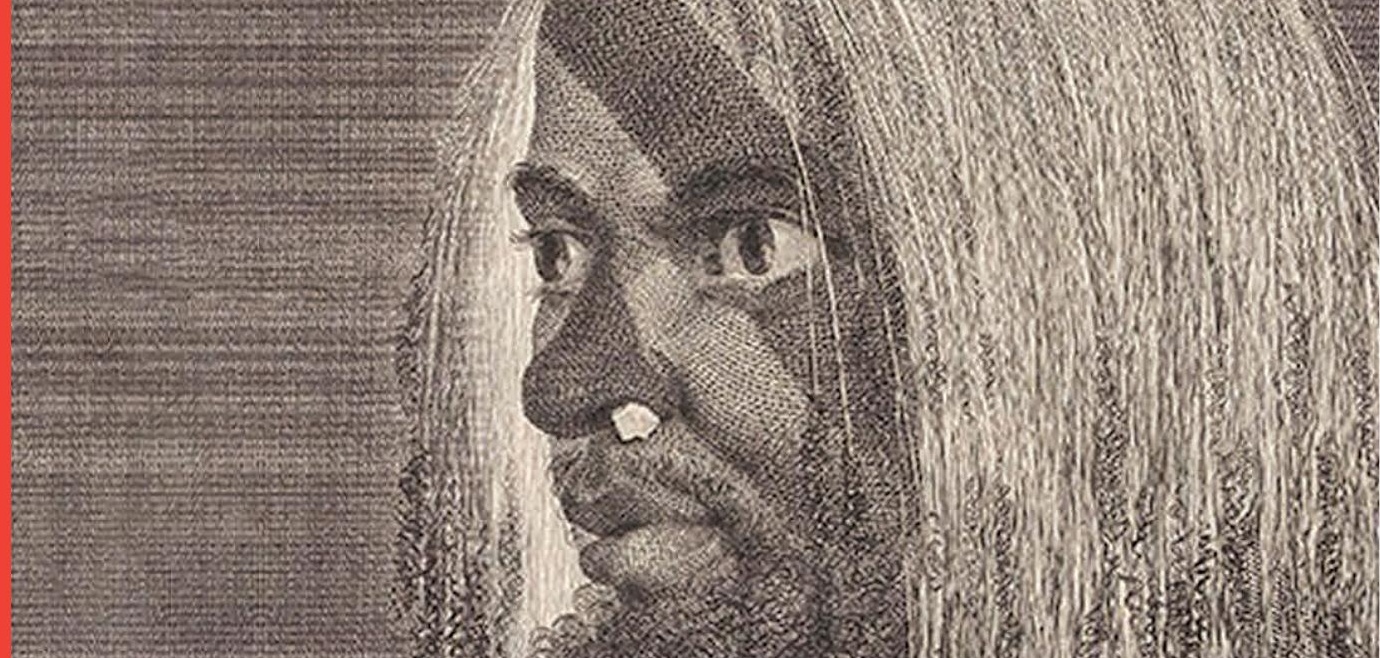
잔. (1) $-12 x^{2}(5)$

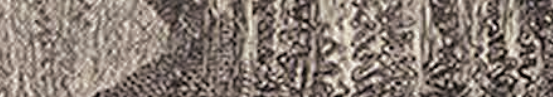
4 in

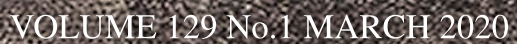




\title{
THE CURIOUS IDEA THAT MĀORI ONCE COUNTED BY ELEVENS, AND THE INSIGHTS IT STILL HOLDS FOR CROSS-CULTURAL NUMERICAL RESEARCH
}

\author{
KARENLEIGH A. OVERMANN \\ University of Bergen \\ University of Colorado at Colorado Springs
}

\begin{abstract}
The idea the New Zealand Māori once counted by elevens has been viewed as a cultural misunderstanding originating with a mid-nineteenth-century dictionary of their language. Yet this "remarkable singularity" had an earlier, Continental origin, the details of which have been lost over a century of transmission in the literature. The affair is traced to a pair of scientific explorers, René-Primevère Lesson and Jules Poret de Blosseville, as reconstructed through their publications on the 1822-1825 circumnavigational voyage of the Coquille, a French corvette. Possible explanations for the affair are briefly examined, including whether it might have been a prank by the Polynesians or a misunderstanding or hoax on the part of the Europeans. Reasons why the idea of counting by elevens remains topical are discussed. First, its very oddity has obscured the counting method actually usedsetting aside every tenth item as a tally. This "ephemeral abacus" is examined for its physical and mental efficiencies and its potential to explain aspects of numerical structure and vocabulary (e.g., Mangarevan binary counting; the Hawaiian number word for twenty, iwakalua), matters suggesting material forms have a critical if underappreciated role in realising concepts like exponential value. Second, it provides insight into why it can be difficult to appreciate highly elaborated but unwritten numbers like those found throughout Polynesia. Finally, the affair illuminates the difficulty of categorising number systems that use multiple units as the basis of enumeration, like Polynesian pair-counting; potential solutions are offered.
\end{abstract}

Keywords: New Zealand Māori, Polynesian number systems, ethnomathematics, undecimal counting, tally counting, numerical cognition

In the long history of cultural misunderstandings, the notion the New Zealand Māori once counted by elevens surely stands as one of the most peculiar. The earliest mention of this "remarkable singularity" (Craik 1830: 417) is found in an 1825 article by Adelbert von Chamisso, the German naturalist known for his work on Oceanic languages. At the claim the Māori number system was based on twenty (von Chamisso 1825: 27), a footnote inserted by the French translator, René-Primevère Lesson, reads, "Error. The arithmetic system of the Zealands is undecimal, and the English are the first to propagate 
this false idea. (L.)" (as translated). ${ }^{1}$ Lesson, a naturalist himself, had recently returned to France from the 1822-1825 Pacific expedition of the corvette Coquille. Lesson would become even more closely linked to the idea the New Zealand indigenes counted undecimally by a letter he wrote to Adriano Balbi, the Italian geographer who published its content in his 1826 Atlas Ethnographique du Globe. According to Balbi (1826: 256-57, as translated from the original French),

With regard to the language of New Zealand, ${ }^{[2]}$ we shall notice that the author of the grammar has made a serious error by indicating as decimal the number [system] of the Zealands, which is obviously undecimal, as several very intelligent natives have given evidence to Mr. Lesson. This naturalist scientist, who has kindly communicated to us the results of his researches on this subject, expresses himself in the following manner in the letter he addressed to us. "We placed coins in front of [the informants], and at the number ten they always said kagnadou, and katekau for 11. Then we removed a coin and said katekau; they answered negatively. Various other carefully conducted experiments allow us to conclude their way of counting, both embarrassing and inconvenient, was purely undecimal; that eleven elevens formed their hundred. The natives who frequent the English missionaries, by the habit they have of hearing them say ten for katekau, are not very fixed on their way of counting, while the natives of the remote villages count 121 for their hundred.

\section{Example.}

$\begin{array}{llll}11 & \text { Katekau Kotahi. } & 77 & \text { Katekau Kawitou. } \\ 22 & \text { Katekau Kadoua. } & 88 & \text { Katekau Kawadu. } \\ 33 & \text { Katekau Katodou. } & 99 & \text { Katekau Kaïwa. } \\ 44 & \text { Katekau Kawa. } & 110 & \text { Katekau Kagnaoodou. } \\ 55 & \text { Katekau Kadima. } & 121 \text { Karaou. } \\ 66 & \text { Katekau Kaono. } & 1331 \text { Kamano. }\end{array}$

Despite the obsolete orthography used, the terms attributed to Lesson by Balbi recognisably contain the usual words for one through ten (kotahi, rua, toru, wha , rima, ono, whitu, waru, iwa and tekau), hundred (rau) and thousand (mano). The words are strung together oddly, as the more typical way of saying eleven would be kotahi tekau mä tahi, glossed as (one) ten and one.

Contemporary author George Lillie Craik (1830: 417) would further detail the alleged undecimal vocabulary: "The New Zealand method of numeration is, according to $\mathrm{M}$. de Blosseville and M. Balbi, very peculiar, being not decimal, but undecimal, or proceeding by successive multiples of eleven. Thus, after ascending to eleven, they say for twelve eleven and one, for thirteen eleven and two, \&.c., till they come to twenty-two, which they 
call twice eleven." Jules Poret de Blosseville was the Coquille's navigator and geographer for the 1822-1825 expedition, as well as Lesson's close friend (Rallet 1953); Craik's reference to Balbi includes, in a footnote, the applicable pages of his 1826 Atlas. Craik (1830: 417) admitted the remarkable singularity of counting by elevens was contradicted by Samuel Lee's 1820 grammar of the Māori language, wherein numbers were "arranged upon the common decimal principle". There is an interesting context to this passage in Craik, the gist and significance of which are discussed below in connection with whether undecimal counting was a prank, a misunderstanding or a hoax.

In 1839 , the posthumously published papers of Wilhelm von Humboldt, the German linguist known for his work on South Sea languages, contained an essay whose content so greatly resembled what Balbi had published that at least one contemporary, August Friedrich Pott (1847: 75), also a linguist, connected it to Lesson. Its introduction, written in German by von Humboldt's research associate, Johann Buschmann, stated the essay had been found among von Humboldt's papers. As summarised by Buschmann (in von Humboldt 1839: 763), the essay, undated and described only as written by an anonymous Frenchman, claimed the word tekau meant eleven, not ten, and that "die NeuSeeländer" in general followed an undecimal system, rather than a decimal one. The essay was then reproduced verbatim (and is translated here from the original French):

\section{Numeration of New Zealanders}

The authors of the Zealandian grammar have undoubtedly made a mistake, by giving as decimal the number system of the peoples living in the Antarctic islands of New Zealand, whose number system is evidently undecimal, as we have proved by means of several native intelligences. So, placing coins, small stones, etc., before a native of the Thames, this islander (and we repeated the experiment in every possible way), when ten were placed before him, said $k a-g n a-d u$, and katekau at eleven. By removing the 11 th item and thus reducing the total to 10 and saying katekau in the numerical manner of the missionaries, no, said several natives from Mercury-Bay and Thames, ka-gna-du, ${ }^{3}$ which they pronounce kagniadou following the French way. Several successive experiments, varied, allow us to obtain numbers very different from those known, and to conclude that among these people numbers are undecimal. The English missionaries, almost all artesans, with the exception of Mr. Kendall, an educated man, have never been able to appreciate a manner of counting so opposite to their own, and in their grammar they made katekau, or ten of eleven units, a worthless term they do not know how to report. Hence the inconvenience of consulting the Kiddi-Kiddi [Kerikeri] natives on their former numbers, for in their daily relations with the whaling ships they have had the strength to bend their way to count according to that of civilised peoples, so too, they do not have very distinct ideas of what they must call katekau, 
and the information they are asked about varies from one native to the next. Eleven units make the Zealandian ten, eleven of their tens the hundred, and eleven of their hundreds the thousand, as follows:

\begin{tabular}{|c|c|c|}
\hline $10-k a-g n a-d u$ & $22-$ & kadoua \\
\hline 11 - katekau & $23-$ & kadoua matahi etc. \\
\hline 12 - katekau matahi & $33-$ & katodou \\
\hline $13-\longrightarrow$ madoua & $44-$ & kawa \\
\hline $14-\longrightarrow$ matodou & $55-$ & kadima \\
\hline $15-\longrightarrow$ maоua & $66-$ & kaono \\
\hline $16-\longrightarrow$ madima & $77-$ & kaouitou \\
\hline $17-\longrightarrow$ maono & $88-$ & kaouadou \\
\hline $18-\longrightarrow$ maouitou & $99-$ & kaїоиа \\
\hline $19-\longrightarrow$ maouadou & $110-$ & kagnaoudou \\
\hline $20-\longrightarrow$ maouiva (sic) & $121-$ & karaou (hundred) \\
\hline $21-\longrightarrow$ magnadou & 1331 & kamano (thousand) \\
\hline
\end{tabular}

(unnamed Frenchman, in von Humboldt 1839: 763-64)

At the essay's conclusion, Buschmann (in von Humboldt 1839: 437-38, 764) said he had compared the numbers 22 to 110 to those in Lee's 1820 grammar and, based on his experience as a linguist, judged them to be erroneous, since tekau had been omitted and without it, they were simply a recapitulation of the numbers one through ten.

Beyond its similarities with Balbi's account, highlighted by Pott (1847: $75)$, the essay contains two clues suggesting Lesson was likely its otherwise anonymous French author. First, it names Thomas Kendall, the English missionary known for his involvement in early attempts to document the Māori language. Von Chamisso (1821a: 388; 1821b: 413) identified Māori numbers as vigesimal in the second volume on the 1815-1818 voyage of the Rurick, but he had corrected this to decimal by the third volume $(1821 \mathrm{c}$ : 440-42), attributing the error to Kendall's initial confusion over pair-counting and its correction to their subsequent communication and his own consultation of Lee's 1820 grammar. In his translator's correction of von Chamisso's 1825 volume, Lesson (1827a: 91) identified the error as having been propagated by the English; he also associated Kendall with Lee's book, A Grammar and Vocabulary of the Language of New Zealand, which Lee published in 1820 based on material from Kendall. Second, the essay lists three places the alleged informants were from-Kiddi-Kiddi [Kerikeri], Mercury Bay and Thames - all located in the northeastern part of New Zealand's North Island, admitting the possibility they might be correlated with the Coquille's movements. And 


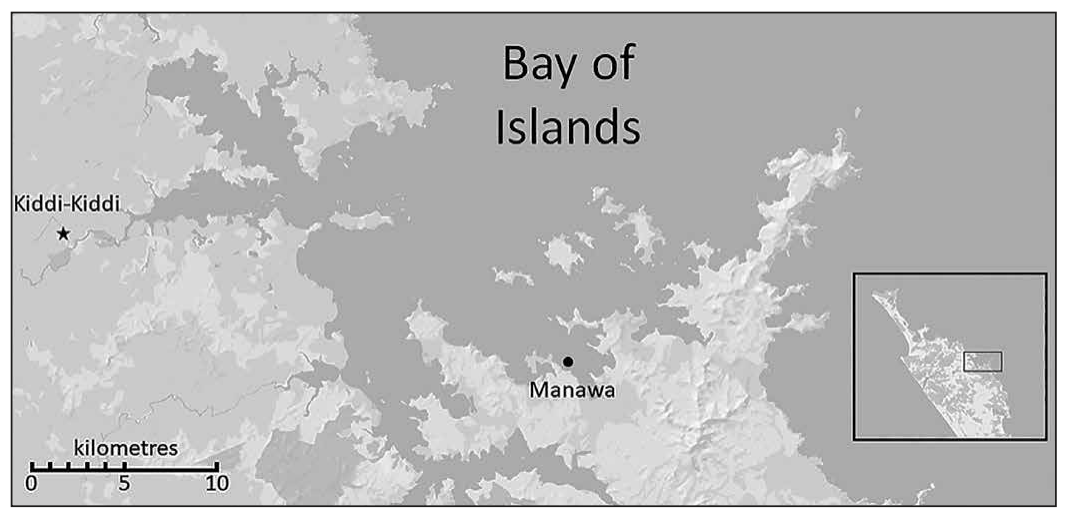

Figure 1. The Coquille's 1824 visit to New Zealand. The ship sighted land on 2 April, anchored at Marion 3 April (not shown) and Manawa 4-16 April and got underway for Rotouma [Rotuma], an island north of Fiji, on 17 April (Duperrey 1829: 84-87). While the positional data put the ship off the North Island's northwest tip, this was undoubtedly an error of longitude, as was typical of the technology of the day; often the ship was recorded as being over land or too far away from it for anyone to have gone ashore. Given the name Manawa and Lesson's frequent mention of Kiddi-Kiddi [Kerikeri], the ship was likely anchored in the Bay of Islands, as was common in the period (Findlay 1851: 712-13), perhaps in Manawaroa Bay, given the similarity of the names. Created by the author using images in the public domain.

in April 1824, the ship did stop for two weeks at Manawa, part of the North Island's Bay of Islands (Duperrey 1829: 84-87; Fig. 1). This visit could have provided Lesson and Blosseville an opportunity to quiz the inhabitants numerically as they interacted with them in the performance of their other duties. Lesson in particular was collecting, among other specimens, Māori names for local species of flora and fauna. He was also impressed enough by the waterfall at Kerikeri to mention the site in many of his publications.

In addition to Lee's grammar, other vocabularies and dictionaries of the period showed Māori numbers as decimal: an earlier vocabulary by John Savage (1807), who had visited the Bay of Islands in 1805, and two later dictionary series, one by Robert Maunsell $(1842,1862)$ and another by the Rev. William Williams and his son, the Rev. William Leonard Williams $(1844,1852,1871,1892)$. While neither Lee, Savage nor Maunsell mention undecimal counting, the elder Williams most certainly did: 
The Native mode of counting is by elevens, till they arrive at the tenth eleven, which is their hundred; then onwards to the tenth hundred, which is their thousand: but those Natives who hold intercourse with Europeans have, for the most part, abandoned this method, and, leaving out ngahuru, reckon tekau or tahi tekau as 10, rua tekau as 20, \&c. (Williams 1844: xv)

Beyond crediting an unflattering decimal rehabilitation to European influence, Williams senior (1844: xv) made no attempt to reconcile the decimal numbers in his dictionary series with the purported practice of counting with them undecimally, though he would suggest Māori were following "the principle of putting aside one to every ten as a tally". American mathematician Levi Leonard Conant (1896: 123) speculated that "[e]arly observers among [the Māori], seeing them count 10 and then set aside 1, at the same time pronouncing the word tekau, imagined that this word meant 11 , and that the ignorant savage was making use of this number as his base". Based on a characterisation of the events communicated to him by the junior Williams, Conant would later report the incident as a "misconception" that "found its way into the early New Zealand dictionary, but was corrected in later editions" (p. 123). In actuality, the material was not corrected but simply removed without comment; further, it remained in the second (1852) edition of the Williams dictionary and was not removed until the junior Williams took over the series with the third edition (1871).

\section{A PRANK, A MISUNDERSTANDING OR A HOAX?}

Just before describing the remarkable singularity - in fact, in the immediately preceding paragraph - Craik (1830: 417) observed the South Sea Islanders were known "to amuse themselves with that sort of wit which [Jonathan] Swift calls 'selling a bargain'”. He provided, as an example:
An instance of this occurred a few years ago. A young missionary, who was reading a book of travels in Sir Joseph Banks's library, was observed every now and then to burst out into a violent fit of laughter; and on the cause of this being asked, it was found that he was reading over a vocabulary in which the natives had cheated the scientific compiler, by giving such answers to his inquiries, that, had any future voyager attempted to use the work of his predecessor, no very good opinion would have been entertained of his morals, and he would have been far distant from the attainment of any object for which he might think he was asking. (p. 417)

The missionary in question might well have been reading the Tongan number words collected and published by Jacques de Labillardière (1799), as the title of the book containing it was listed in the Banks library catalogue as early as 1800 (Dryander 1800: 313), doubtless reflecting Sir Joseph's own great 
interest in South Seas exploration, as he had accompanied Cook on his first Pacific voyage (1768-1771). Labillardière had been a member of the 17911792 expedition searching the South Seas - in vain, as it happened — for signs of the lost 1788 expedition of Jean-François de Galaup de La Pérouse. ${ }^{4}$ Despite the serious purpose of his own expedition, on visiting Tonga, Labillardière "had the perseverance to interrogate the natives, and obtain particular names for numbers as high as 1,000,000,000,000,000!!" (Martin 1818: 370-71). These included words that were not in actuality numbers but "Tongan names for sundry unseemly anatomical details, and the polysyllabic word given for $10^{15}$ was actually an invitation to eat up the things which had been named previously!" (Tee 1988: 402). ${ }^{5}$ Craik's sly if oblique reference, positioned to contextualise Balbi's description of Lesson's eyewitness account, suggests he suspected the local inhabitants were having similar fun with a naïve foreign visitor, especially since both situations involved numerical vocabulary.

Interestingly, apart from the footnote in von Chamisso's 1825 article, Lesson does not appear to have published his own account of what would have been a notable discovery. No trace of it is found in his own extensive writings on the Coquille's voyage, his discoveries in multiple disciplines, his impressions of the Oceanic peoples generally, his observations of the New Zealand people specifically or his notes on Rotouma and Oualan [Kosrae], islands visited after New Zealand in 1824 (1825a, 1825b, 1825c, 1826, 1827a, 1827b, 1828a, 1828b, 1829a, 1829b, 1829c, 1830; Lesson and Garnot 1826). While several of these publications contain numerical vocabularies, three stand out in particular. His 1826 volume not only highlighted the use of decimal numbers in the Caroline Islands but also compared them to those in the work by von Chamisso he had translated and corrected in 1825 (Lesson and Garnot 1826: 84). His notes on Rotouma and Oualan, published the same year, included their numbers (Lesson 1825b: 75-76; 1825c: 43). A remark on finding unusual numbers in New Zealand would surely have found any or all of these a suitable venue.

Neither did the ship's commander, Louis Isidore Duperrey $(1825,1826$, 1828), nor his second-in-command, Jules Dumont d'Urville (d'Urville et al. 1829), mention what would certainly have been a singular discovery on the part of their crew. However, Lesson's friend and colleague, Blosseville, whom Craik (1830: 417) had associated with an early report, apparently did mention it by letter to another colleague, Nell de Bréauté. This correspondence, reported third-hand by yet another gentleman-scholar of the period, Hungarian astronomer Baron Franz Xaver von Zach, was brief and undetailed:

Mr. Nell de Bréauté writes that, according to the communications he has received from M. de Blosseville, the map of the Carolinas, and especially that of New Zealand, is much changed by the observations made in the 
expedition of the Coquille by Captain Duperrey. On this last island, a system of undecimal numbering was found in use. (von Zach 1826: 121, as translated from the original French)

As for Blosseville's (1826a, 1826b) own publications on the voyage, the remarkable singularity is again conspicuously missing. Had the explorers thought the discovery a real one, they would surely have formally claimed its attendant publicity, since the purpose of publishing a voyage was to promote its accomplishments, highlight its importance, assure patrons the investment had been sound and elevate the stature of the officers and scientific explorers. Since the extraordinary claim would continue to gather attention for the next century, these omissions are otherwise inexplicable.

Yet the affair is not so easily attributed to a misunderstanding on Lesson's part, as he encountered many Pacific number systems during his time on the Coquille and was familiar with the literature. In 1825 he had, as noted earlier, contested von Chamisso's identification of New Zealand numbers as vigesimal. In his notices on Rotouma and Oualan, also published in 1825, he included number words, comparing them to Pacific numbers generally and concluding their similarities suggested relatedness among the Oceanic peoples (Lesson 1825b: 75-76; 1825c: 43). His grammar of the language of Madagascar contained its numbers (Lesson 1827a: 97-98). In his first volume on zoology, he drew upon his 1824 contact with Oualan, Pénélap [Pingelap] and Doublon [Tonowas], von Chamisso's vocabularies for Bisaya [Cebuan], Pampango [Kapampangan], Tagala [Tagalese], Chamori [Mariana Islands], Radack [Marshall Islands], Eap [Yap] and Ulea [Woleai] (von Chamisso 1821b) and Wilson's vocabulary for Pelew [Palau] (Keate 1788), concluding "decimal numeration is the only one used, and, although the names of the numbers vary, the arithmetic system is the same" (Lesson and Garnot 1826: 84, as translated). In 1828, he compared the numbers of Tahiti to those of Madagascar and the Tahitian language to that of New Zealand; for the numbers, he again said their similarities likely arose from a common source, even though the peoples in question were "so distant and distinct from one another" (Lesson 1828a: 279-80, as translated). And in 1829 , he published numerical vocabularies from his travels in the Papuan region, including New Ireland, Doréry, Salwatty, Tidore, Waigiou and the New Guinea interior (Lesson 1829a: 103, 164-66). All in all, excepting the 1825 footnote, Lesson's work on number systems was factual, informed, contextualised and entirely commonplace. It was so unremarkable, in fact, that it cannot easily be reconciled with the possibility he may have misunderstood the numbers he encountered in New Zealand.

The prospect of the affair being a hoax on the part of Lesson and Blosseville cannot be discounted, even though, at least initially and indirectly, they were 
willing to attach their names to the story. They were after all young, more than a little disenchanted with seafaring and keen to establish their names and reputations (Rallet 1953). And it is tempting to construe the affair as having started with a printer's error. Von Chamisso's (1825: 27) text reads, "le système arithmétique [est] fondé sur une échelle de vingt, comme dans la Nouvelle-Zélande". Lesson's footnote correction states, "(2) Erreur. Le système arithmétique des Zélandais est undécimal", where "un décimal" might have been intended and, moreover, would have been consistent with both von Chamisso's 1821 correction and Lesson's published work on Pacific number systems. As youthful skylarks or prideful justifications go, embellishing this exchange as a fantastical pseudo-scientific tale would have been relatively benign. And as Buschmann (in von Humboldt 1839: 437-38) would later note, the resultant number words were not something an experienced linguist would find credible. Indeed, the same sort of error helped identify as specious the lists of South Sea number words announced by Lanyon-Orgill (1979) some 150 years later (Clark 2011; Geraghty 1983).

Whatever the actuality of the case, if Lesson and Blosseville hoped the lack of formal publication on their part might make the incident fade away, they were to be disappointed, as the notion would continue to percolate through scholarly discourse. By the late nineteenth century, the remarkable singularity was repeated in anthropological works, encyclopaedias, mathematical volumes, numerical treatises and scholarly reviews with greater or lesser credulity and enthusiasm. Some merely reiterated the rumour as fact (Cantor 1880: 9; Fink 1890: 6; Grabowsky 1889: 96; Günther 1888: 1; Reinach 1890: $615)$, while others attempted to explain or make sense of the practice along the same lines the senior Williams had once employed: as putting aside one item to represent every ten, misunderstood by European observers as counting by elevens (Conant 1896: 123); as calling out the attainment of the tally, not the number itself (Codrington 1885: 246); or as humorous analogue to the baker's dozen (Reuleaux 1885: 275). However, at least one scholar seems to have doubted the report's veracity, saying it needed confirmation or refutation (Schubert 1888: 292). Others merely listed Māori numbers as decimal (Peacock 1845: 385) or discussed their structure without mentioning the remarkable singularity (Tylor 1871:232), suggesting these authors either were unfamiliar with the tale or rejected it as nonsense on principle.

By the twentieth century, no serious linguist or anthropologist believed the tale, though a few simple, unsourced mentions were made by synthesists or peripheral figures: "In New Zealand, words for $11^{2}$ and $11^{3}$ have been found" (Henrici 1964: 291); "in one case, the one-extra digit system did arise: after the fingers, the whole hand was also counted. This is evidenced, for example, by representations for the 1st, 2 nd, and 3rd powers of 11, and also the representations $12=11+1,13=11+2,22=11 \times 2$ for New Zealanders" 
(Berjoskina 1982: 32, as translated from the original Russian). Other reports, even more recent and a bit more detailed, recognised the notion as mistaken but suggested the idea and number words for $11^{2}$ and $11^{3}$ had originated with the Williams dictionary, as by this time the affair's Continental origins had been forgotten:

In New Zealand, the missionary William Williams initially misunderstood Maori counting practice, and in the first edition of his Maori-English dictionary he claimed that the Maori counted by elevens, and he gave words purported to mean $11^{2}$ and $11^{3}$ : actually, they meant $10^{2}$ and $10^{3}$. That blunder was corrected in all [sic] later editions of Williams's dictionary — but reports have been published in recent years claiming that the Maori used 11 as the base of their number system. (Tee 1987: 1; 1988: 403; in both, Tee cites Berjoskina 1982; Conant 1896; Henrici 1964; and Williams 1844. Kahaner's 1993: 65 near-verbatim account appears to have been based on Tee's 1987 and 1988 publications.)

It is not difficult to explain why such ridiculous farce might proliferate and persist: "No apparent reason existed for this anomaly, and the Maori scale was for a long time looked upon as something quite exceptional and outside all ordinary rules of number-system formation" (Conant 1896: 123). This estimation was accurate because, except for Māori, only one other case of undecimal counting has ever been asserted (for the Pañgwa, a Bantuspeaking people of Tanzania), but this report, like that on Māori, could not be confirmed (Hammarström 2010: 24). Since no undecimal systems have ever been found (Comrie 2011), the discovery of one at any point in time would indeed be worthy of remark.

\section{WHAT THE CURIOUS IDEA ILLUMINATES ABOUT POLYNESIAN NUMBERS}

If now half-forgotten and dismissed as historical curiosity, the idea that Māori once counted by elevens nonetheless offers valuable insights for contemporary cross-cultural research in number systems. First, the very oddity of the tale has acted to conceal the counting strategy used: setting aside every tenth item as a tally. This practice is not just pragmatic and clever, it is also key in understanding highly elaborated, unwritten numbers like those of the Polynesians; moreover, it can challenge assumptions about how concepts of exponential value might emerge. Second, the tale illuminates some of the reasons why people enculturated into notationally mediated numbers can find it difficult to appreciate ones that are highly elaborated but unwritten. The third and final insight is more definitional: whether Polynesian number systems are appropriately categorised as vigesimal or decimal, the substance of Kendall's confusion and perhaps the specific point 
of disagreement between von Chamisso and Lesson. Polynesian number systems, which count not just singly but with multiple objects as the unit of enumeration, share traits with both decimal and vigesimal systems, such that neither category is adequately descriptive.

\section{Counting Exponentially by Setting Aside Every Tenth Item}

Those who must work physically_-including counting lots of objectsoften develop strategies to make their jobs easier, and the Polynesians were no exception in this regard. Tallying by setting aside every tenth item as a counter is a brilliant method of reducing both the physical and mental effort of counting. Physically speaking, the method eliminates the need to create the increasingly large and correspondingly heavy and bulky groups implied if single objects were combined as groups of tens, groups of tens as hundreds, groups of hundreds as thousands and so on. The method reduces handling to a matter of sorting objects into two groups - every nine go into the "counted" pile, while every tenth goes into the "tally" pile - with handling reduced even further when the counted unit is multiple, instead of single. The method is also extensible from units and tens, to tens and hundreds, hundreds and thousands, thousands and tens of thousands and so on, with each new pile of items set aside as tallies understood to mean ten times the previous register. Mentally speaking, sorting and setting aside makes counting a matter of repetitively counting to ten, reducing demands on cognitive processes like attention and memory. The method can be used without needing any kind of ancillary record, since the enumerated objects themselves serve this purpose as they are rearranged, and this further reduces both the physical and mental labour of enumeration.

Tally counting creates temporary piles of objects representing different exponential weights - a pile of tens, a pile of hundreds and so on. An object assumes a value ten times greater than its counterparts by being sorted into a different pile; this creates a literal place value, exponential weighting acquired from being physically located in a different pile. The piles effectively comprise a representational device, an ephemeral abacus: an abacus because it instantiates exponential grouping and facilitates the exchange of value between groups; ephemeral because the device persists only while counting is performed. While such devices are ad hoc and short-lived, they also suggest a mechanism for realising two-dimensional structure in numbers because exponential grouping through sorting is added to the ordinal accumulation of a counting sequence. On this account, numerical structure emerges from exponential distinctions created physically and understood contextually, with linguistic labels emerging to reinforce and perpetuate the exponential distinctions and to help remember and recall the information in the absence of a persisting material device. 


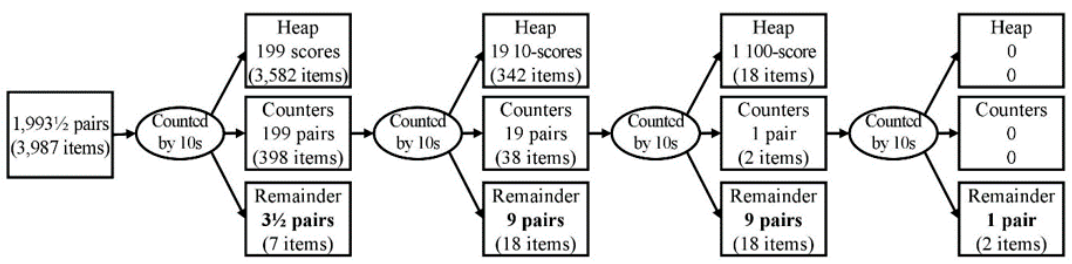

Figure 2. Pair-counting with every tenth pair set aside as a counter. In the first round, 3,987 items counted in pairs $\left(1,993 \frac{1}{2}\right.$ pairs) by tens create 199 scores, of which every tenth pair (199 pairs or 398 items) is retained as a counter and 3,589 items $(3,582$, or nine of every ten pairs, plus the remainder of seven) are added to the heap of items counted. In the second round, 398 items counted in pairs (199 pairs) by tens create 19 ten-scores (numerically valued at 20 each), of which every tenth pair (19 pairs or 38 items) is retained as a counter and 360 items (342, or nine of every ten items, plus the remainder of 18) are added to the heap. In the third round, 38 items are counted in pairs (18 pairs) by tens to create one 100 -score (numerically valued at 200$)$, with 36 items $(18$, or nine of every ten items, plus the remainder of 18) added to the heap. In the fourth and final round, two items counted in pairs (one pair) represents one 1,000-score (numerically valued at 2,000). Note: The term heap is taken from Hale's (1846: 247) description of Polynesian counting: "Taking one [item] in each hand, the native, as he throws [the items] into the storehouse, or on to the heap, counts one; for two pairs, he says two; for ten pairs simply ten, and so on".

A Tikopian informant was recorded as using grains of rice to demonstrate the method: he "reckoned nine and then put aside the 10th grain, and so on. Afterwards he reckoned up the tenth grains to reckon the hundreds" 6 (Durrad 1913: 146). Figure 2 shows a detailed example of the method with pair-counting: 3,987 items make 1,9931/2 pairs. The first round of counting, by setting aside every tenth item to act as a tally, leaves 398 items to represent 199 groups of ten pairs (tekau or scores) and a remainder of $3 \frac{1}{2}$ pairs. The second round produces 38 items to represent 19 ten-scores, numerically valued at 20 each, and a remainder of nine pairs. The third round produces two items to represent one 100 -score, numerically valued at 200 , and a remainder of nine pairs. The last round leaves one pair to represent one 1,000 -score, numerically valued at 2,000 . In modern notation, the remainders $\left(3 \frac{1}{2}, 9,9\right.$ and 1) can be multiplied appropriately to produce an anachronistically precise answer: $\left[(1 \times 2,000)+(9 \times 200)+(9 \times 20)+\left(3 \frac{1}{2} \times 2\right)\right]=3,987$. However, words for remainder, like tauwhara in Māori (Best 1906: 166), are common throughout Polynesia and suggest the result might well have been understood as one virtual bundle worth 2,000 and a remainder. 


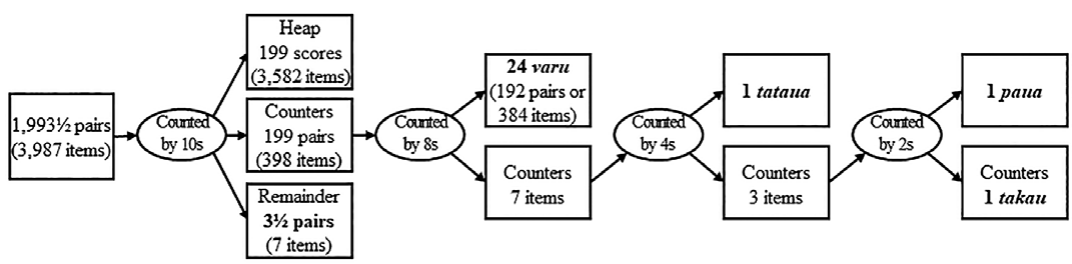

Figure 3. Mangarevan binary counting as an extension of the tally method. The initial value from Figure $2(3,987)$ is used to aid comparison with Figure 3, though the computation yields an amount (24 varu) that exceeds the upper limit for binary counting, which was 10 varu (Hiroa 1938: 417; Janeau 1908: 20 , noting these authors calculated the upper limit somewhat differently). ${ }^{7}$ The first round, which counts by tens, is identical to that of Figure 2 . The 398 counters from the first round are then counted by eights to create 24 varu, perhaps also explaining why the higher unit is called varu, meaning eight. Changing the basis to eight greatly simplifies counting beyond the first round by leveraging productive terms for ten eights, ten fours and ten twos and relations between eight, four and two. Though the amount could be expressed as 24 varu with a remainder, the process is also easily carried out further: of the remaining seven counters, four make one tataua, two make one paua and one makes one takau. The full result would be expressed as rua takau 'a varu tataua pana takau toru, or $[(24 \times 80)+(1 \times 40)+(1 \times 20)+(1 \times 10)+3]$ with one single item (half of a pair) remaining. The method thus has the potential to make the final amount more precise, as remainders are part of the final arrangement. When the unit is four, 3,987 single items make $996 \% / 4$ units, counted as (ta i) takau rua varu paua takau ono, or $[(12 \times 80)+(1 \times 20)+(1 \times 10)+6]$ with three single items remaining. When the unit is eight, 3,987 single items make 498.375 units, counted as ono varu takau varu, or $[(6 \times 80)+(1 \times 10)+8]$ with three single items remaining.

The method can be used with single items, where counting 3,987 yields $[(3 \times 1,000)+(9 \times 100)+(8 \times 10)+(7 \times 1)]$. It is also extensible to counting with multiple units other than pairs: counting 3,987 by fours yields $[(9 \times 400)+(9 \times 40)+(63 / 4 \times 4)]$, while counting the same amount by eights yields $[(4 \times 800)+(9 \times 80)+(8.375 \times 8)]$. Notably, the method explains the curious Hawaiian term for twenty, iwakalua or nine and two, as nine counted in pairs and the last two items set aside as tallies (Fig. 2). It also plausibly underpins the binary steps in one of the Mangarevan counting sequences, a simple extension of the method that incorporates the equivalence heuristics and associated linguistic labels for pairs, fours and eights (Fig. 3).

As René Lesson remarked, Polynesian number words, counting practices and numerical structure are relatively homogeneous across the region. In fact, 
the geographic distribution of traits (Fig. 4) and related practices like rounding suggest that tally counting was likely practised throughout Polynesia. As settlement moved west into the central and peripheral portions of Polynesia, number systems generally lost their elaborate numeral classifiers and acquired the upward shift in value associated with counting by pairs and fours. Some of the higher terms also shifted downwardly in value in the peripheries: while afe means 1,000 and mano 10,000 in Sāmoan and Tongan, mano means 1,000

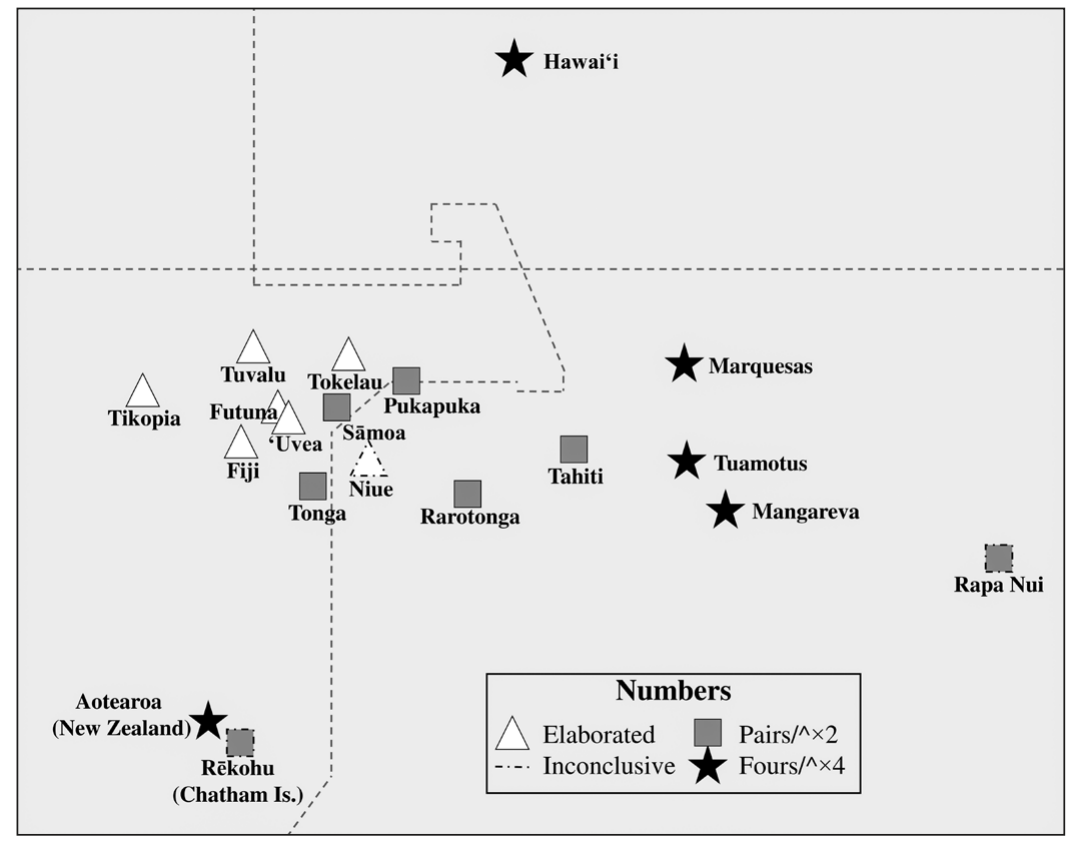

Figure 4. Geographic distribution of counting practices in Polynesia. Throughout Polynesia, counting varies by the type of object being counted. In the western (longest-settled) portion, counting includes the use of elaborate numeral classifiers (white triangles), perhaps as a means of encoding the type of object being counted. In central Polynesia, counting by pairs and fours is characteristic (grey squares), and in most recently settled eastern, northern and southern portions, productive terms are shifted upwardly by a factor of two or four (black stars), as are the base values of terms for hundreds and thousands (not shown). Insufficient information was available to classify Niue, Rapa Nui or Rèkohu according to the type predicted for their geographic location (dashed lines). Historical sources also often fail to differentiate the specific islands or dialects, encountered, instead designating them more generically (e.g., Tonga). 
in the languages of Hawai' $i$, Mangareva, New Zealand, Nukuhiva, Paumotua, Rarotonga and Tahiti (Hale 1846: 247). The downshift and other changes in the value of higher exponential terms may represent more than simply an imperfect memory for infrequently used higher terms, as it also implies tally counting may have acted as a persistent mechanism for structuring numbers decimally and occasioning names at the exponential points.

\section{Notationally Mediated vs. Unwritten Numbers}

If developing a "systematic mathematics requires writing, and hence a non-literate culture cannot be expected to advance mathematics beyond the stage of numeral words and counting" (Tee 1988: 401), it does not follow that unwritten numbers are necessarily unelaborated. Undoubtedly, written notations contribute greatly to numerical and mathematical elaboration, through handwriting effects, which influence written numbers to be conceived as entities in their own right, rather than collections of objects; relational data, whose bulk accumulation becomes feasible through notational concision, enabling numbers to be conceptualised in relational terms; and non-numerical writing, which lets calculations be documented, codified and elaborated, assuming it is available in addition to numerical notations (Overmann 2018a, 2018b, 2019). Yet unwritten numbers span a gamut that includes not just systems with few numbers and relatively little elaboration (e.g., the Mundurucu of Amazonian Brazil count to "about four"; see Rooryck et al. 2017), but also systems with many numbers and counting sequences highly elaborated with numerical relations (e.g., the Māori and other Polynesian societies counted into the tens of thousands and often higher, and their counting sequences were related by heuristics equivaluing terms like twenty counted singly and ten counted in pairs; see Hongi 1909).

Arguably, the use of multiple counting sequences was the crucial circumstance challenging early Western observations of Polynesian numerical practices. Multiple counting sequences, in which various types of items were counted not just one by one but in groups of twos, fours and even eights (Bender and Beller 2014; Campbell 1816; Hale 1846), would have been strange to Westerners more accustomed to counting only singly or counting pairs as two, four, six, eight.

Some confusion was practically unavoidable, as observers were likely to have thought of their own, Western numbers as universal and interpreted what they saw accordingly, the cross-cultural analogue to the "backward appropriation" imposing contemporary notions of numbers on those of the past (Rotman 2000: 40). Stated more strongly, Western numbers, elaborated over several thousand years as a notationally mediated system, act as a conceptual barrier: notations structure and organise numbers in ways informing both how numbers are acquired and what they are understood to be (Schlimm 2018). This creates an idea of what numbers must be, which 
would have made it difficult for men educated in the Western mathematical tradition to appreciate fully the non-Western numbers they encountered on their travels. ${ }^{8}$

The scientific explorers were also likely to have encountered both significant faculty in the interchange of different counting sequences (Clark 1839: 93; Ellis 1826: 441) and some variability in the way counting was practised across locales and individuals (Best 1921), further challenging their attempts at describing and categorising. In addition, they were not just educated men but gentlemen; this made them unlikely to have had much hands-on experience with physical enumeration tasks themselves, as it would be unusual for men of their social status to count lots of objects for purposes like inventories and commerce.

\section{Decimal or Vigesimal?}

Debate over whether Polynesian numbers should be categorised as vigesimal or decimal has continued since the days of Kendall, von Chamisso and Lesson (e.g., Bender and Beller 2006). At issue is the practice of counting with multiples as the unit of enumeration, which upwardly shifts the higher productive terms. In New Zealand, this created a vigesimal appearance (Best 1906); in Hawai' $i$, counting by fours made forty productive (Campbell 1816); in the Marquesas, counting breadfruit by fours shifted productive terms upward by a factor of four (Eyriaud des Vergnes 1877; Handy 1923); and in Mangareva, binary steps emerged to prefigure those of Leibnitz in computational history (Bender and Beller 2014). Multiples-counting differs from vigesimal and decimal counting, though it shares qualities with both. Decimal and vigesimal systems, typically based on human digits, reach twenty by counting the fingers (decimal) or fingers and toes (vigesimal) of a single individual, and then repeating the cycle on the same or additional people. For decimal systems, the number twenty-one represents the initiation of a third cycle, the number forty the completion of the fourth, while for vigesimal systems, twenty-one represents the initiation of a second cycle, forty the completion of the second.

Polynesian pair-counting, in contrast, reaches twenty by counting ten pairs (Table 1); eleven in the sequence has the numerical value twenty-two, while a term meaning remainder would be required to append a half-pair to twenty to achieve the value twenty-one. Its twenty is productive in the same way ten is in a decimal system; forty is analogous, under its logic, to the decimal twenty, representing two complete cycles of counting ten pairs. The logic is decimal, but the numerical amounts correspond to those of a vigesimal system. Pair-counting is thus intermediate between a decimal and vigesimal system, and this can confuse how Polynesian number systems are categorised. For example, Lemaitre (2004) and Nishimoto (2015) identify Austral (Rurutu) 
numbers as vigesimal, when their prototypical form and organisation suggest they are more likely to be just as decimal as other Polynesian numbers. The lack of fit suggests either that new definitions and categories are needed for number systems counting with multiple units, an option that would capture necessary detail but might require more coordination and consensus, or that one of the two distinct categories - decimal for logic, vigesimal for numerical value - should be consistently applied.

Table 1. Prototypical decade formation in decimal, vigesimal and pair-counting systems.

\begin{tabular}{|clll|}
\hline Number & Decimal system & Vigesimal system & Pair-counting \\
\hline 10 & $(\mathbf{1} \times \mathbf{1 0}) \mathbf{1 0}$ fingers & 10 fingers & 5 [pairs] \\
20 & $(2 \times 10)$ & $(\mathbf{1} \times \mathbf{2 0}) \mathbf{1}$ person & $\mathbf{1 0}$ [pairs] (1 tekau) \\
30 & $(3 \times 10)$ & $(1 \times 20)+10$ & 15 [pairs] \\
40 & $(4 \times 10)$ & $(2 \times 20)$ & 20 [pairs] $(2$ tekau $)$ \\
50 & $(5 \times 10)$ & $(2 \times 20)+10$ & 25 [pairs] \\
\hline
\end{tabular}

Note. Productive terms are highlighted in bold.

$* * *$

Tally counting and the ephemeral abacus it instantiates have also been documented in yam counting in Papua New Guinea (Döhler 2018: 16-18; Williams 1936: 226-27). In these senary systems, exponential structure can reach an impressive seventh power of six (279,936; see Evans 2009: 328; Fig. 5), rivalling that of Polynesia, where counting to the sixth power of ten (million) was attested before significant European influence toward standard decimalisation had occurred (Hale 1846: 247). However related Polynesian and Papuan exponential counting might be through regional proximity, the universality of counting practices across the globe generally suggests that the manuovisual engagement of material artefacts informs and perhaps underlies the development of complex, two-dimensional structure in numbers. This in turn challenges the idea such structure develops without involving material forms and implies devices have a greater role than being simply the passive recipients of mental content.

An awareness of the potential relation between such counting/sorting strategies and the realisation of exponential concepts like hundreds and 


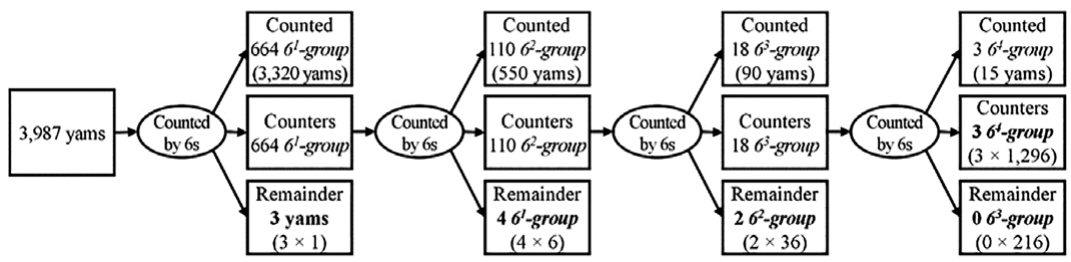

Figure 5. Senary yam counting in Papua New Guinea. The initial value from the previous figures $(3,987)$ is used to aid comparison. Williams (1936: 22627 ) described yam counting as a deliberative process involving multiple participants wherein tallies are carefully counted and verified at each stage. The uppermost boxes were retitled from "Heap" to "Counted" to express this difference from the more rapid Polynesian sorting method, but it is worth noting some of the scrupulousness Williams observed might have reflected an unfamiliarity with senary counting, as the Keraki villagers (whose own numbers were "a 1-5 system") were said to have borrowed the method from the Gambadi and Semariji languages. In the first round, 3,987 yams are counted by sixes to create 664 groups valued at six each (3,320 yams), of which every sixth (664 yams) is set aside as a counter, with three yams left over. In the second round, 664 yams are counted by sixes to create 110 groups valued at 36 each (550 yams), of which every sixth (110 yams) is set aside as a counter, with four yams (worth six each) left over. In the third round, 110 yams are counted by sixes to create 18 groups valued at 216 each (90 yams), of which every sixth (18 yams) is set aside as a counter, with two yams (worth 36 each) left over. In the fourth and final round, 18 yams are counted by sixes to create three groups valued at 1,296 each (15 yams), of which every sixth (three yams) is set aside as a counter, with no yams (worth 216 each) left over. The three yams set aside as counters in the final round are valued at 1,296 each.

thousands is conspicuously absent from the literature on number systems, where one gains instead an impression numbers are purely mental entities originating in ratiocination or language alone. ${ }^{9}$ As a referee to Overmann 2018a commented, "what the vast majority of cultures actually have [are] verbal representations of quantities, often without any material representations of them"- that is, many words but few devices. Yet this view may assume an overly narrow definition of representational form, which can be biological (fingers), symbolic (notations) or ephemeral (counting/sorting). To those who rightfully object that temporary piles of sorted objects hardly constitute an artefact as one is usually defined, the converse must be noted as well: while admittedly ephemeral, the abaci 
created by Polynesian tally counting are nonetheless material enough to suggest exponential realisation involves more than mental effort. Further, the manuovisual stimuli they provide would prompt, scaffold and facilitate the conceptualisation process, making concepts more attainable and therefore more likely. Ultimately, Māori tally counting may find its greatest utility in foregrounding the material we may be missing in a way that puts to the test the idea of an unassisted-brain origin for numbers.

In sum, the idea that Māori once counted by elevens can be more than what it has become, an abandoned, bizarre, nineteenth-century relic of cultural misunderstanding. It can let us examine how Polynesians actually counted, consider the material and mental implications of setting aside every tenth item as a tally and admire the method's practical efficiency and its effects on numerical structure and organisation. It can provide us with a novel opportunity to look past our notationally mediated, Western constructs of what numbers are and must be and discard their constricting effects on how we understand numbers that are neither. And it can enable us to resurface the issue of how Polynesian numbers are appropriately categorised, suggesting either the expansion of current categories or a greater consistency in their application. Above all, it can let us appreciate the beauty of cross-cultural numerical structures, the pragmatic brilliance of Polynesian counting and the wonderful opportunity to examine them afresh through the historical lens.

\section{ACKNOWLEDGEMENTS}

This project has received funding from the European Union's Horizon 2020 research and innovation programme under grant agreement No. 785793. Valeria Markova, University of Bergen, assisted with translating Berjoskina's work from its original Russian. Andrea Bender, University of Bergen, offered helpful comments on an early draft. Finally, the manuscript benefited greatly from insightful comments from an anonymous reviewer and the editor.

\section{NOTES}

1. All translations were performed by the author.

2. There are two indigenous languages of New Zealand, Māori and Moriori. The historical references consulted for this research do not differentiate them but instead refer to "the language" of New Zealand. In the context of the idea of counting by elevens, however, it seems probable that Māori was intended, given Lesson's contact with the northern tip of North Island (Fig. 1) and Moriori's association with the more southerly Chatham Islands (Deighton 1889).

3. In a footnote to the original material, Buschmann (in von Humboldt 1839: 763) noted Lee's grammar gave Ka nga údu for 10 (also see Lee 1820: 17). 
4. The La Pérouse disappearance would capture the national attention for decades, to the point that novelist Jules Verne included it in his 1869-1870 serialisation of Twenty Thousand Leagues Under the Sea. As history would ultimately discover, the two ships of the La Pérouse expedition had wrecked amid the Solomon Islands, where they, along with probable survivors, would remain unlocated for the next forty years.

5. Some of the terms were so indelicate Martin declined to list them explicitly, referring interested readers instead only to the general vocabulary included in the volume.

6. Durrad (1913: 146) also noted the Tikopian informant became confused in trying to extend the counting method from hundreds to thousands. This was interpreted here as indicating a lack of practice and not as disconfirming the counting method.

7. Hiroa (1938: 417) said the upper limit of the binary counting system was 800 , or 10 varu without any of the lower units. Janeau (1908: 20) put the upper limit at 1,440 , or 9 varu counted in pairs. This is essentially the same limit noted by Hiroa, as half of 1,440 (720) plus the maximum in all lower units yield 799 (9 varu, 1 tataua, 1 paua, 1 takau and 9 tauga), or one less than 800 counted in pairs (and numerically equivalent to 1,598). As 10 varu (Hiroa's method), the upper limits are 800 (singles), 1,600 (pairs), 3,200 (fours) and 6,400 (eights); as 9 varu (Janeau's method), the upper limits are 720 (singles), 1,440 (pairs), 2,880 (fours) and 5,760 (eights); as 9 varu plus maximum lower units, the upper limits are 799 (singles), 1,598 (pairs), 3,196 (fours) and 6,392 (eights).

8. In perhaps the most extreme case of this conceptual conflation, the Spanish reportedly showed the Rapanui written notations to elicit their words for numbers (Fedorova 1993; González de Haedo 1770).

9. For example, Dutch mathematician Luitzen Brouwer (1981: 90) viewed numbers as emerging from an "inner experience" of the mind. In comparison, American linguist Noam Chomsky (1988: 169) claims the "human number faculty [to be] essentially an 'abstraction' from human language, preserving the mechanism of discrete infinity and eliminating the other special features of language".

\section{REFERENCES}

Balbi, Adriano, 1826. Observations sur la classification des langues océaniennes. In Atlas Ethnographique du Globe, ou Classification des Peuples Anciens et Modernes d'Après Leur Langue. Vol. 1. Paris: Paul Renouard, pp. 230-78.

Bender, Andrea and Sieghard Beller, 2006. "Fanciful" or genuine? Bases and high numerals in Polynesian number systems. Journal of the Polynesian Society 115 (1): 7-46.

2014. Mangarevan invention of binary steps for easier calculation. Proceedings of the National Academy of Sciences of the United States of America 111 (4): $1322-27$.

Berjoskina, E.I., 1982. O matematicheskikh metodakh drevnikh (k istorii sistem schisleniy). Istoriya i Metodologiya Estetvennykh Nauk 29: 31-40. 
Best, Elsdon, 1906. Maori numeration: Some account of the single, binary, and semivigesimal systems of numeration formerly employed by the Maori. Transactions and Proceedings of the New Zealand Institute 39: 150-80.

1921. Huru, or ngahuru: Notes on a widespread word denoting ten, and its many variant forms in use throughout the Pacific and Indian Ocean regions. New Zealand Journal of Science and Technology 3 (5-6): 248-56.

Blosseville, Jules Poret de, 1826a. Mémoire géographique sur la Nouvelle-Zélande. In J.-B. B. Eyriès and C. Malte-Brun (eds), Nouvelles Annales des Voyages, de la Géographie et de l'Histoire. Vol. XXIX. Paris: Librairie de Gide Fils, pp. 5-35.

1826b. Voyage du Capitaine Edwardson à la côte méridionale de TavaïPoenammou, du 6 novembre 1822 au 28 mars 1823. In J.-B. B. Eyriès and C. Malte-Brun (eds), Nouvelles Annales des Voyages, de la Géographie et de l'Histoire. Vol. XXIX. Paris: Librairie de Gide Fils, pp. 145-90.

Brouwer, Luitzen E.J., 1981. Brouwer's Cambridge Lectures on Intuitionism. Cambridge: Cambridge University Press.

Campbell, Archibald, 1816. A Voyage Round the World, from 1806 to 1812; in Which Japan, Kamschatka, the Aleutian Islands, and the Sandwich Islands Were Visited. New York: Broderick and Ritter.

Cantor, Moritz, 1880. Vorlesungen Über Geschichte der Mathematik. Vol. 1. Leipzig: Druck und Verlag von B. G. Teubner.

Chomsky, Noam, 1988. Language and Problems of Knowledge: The Managua Lectures. Cambridge, MA: MIT Press.

Clark, E.W., 1839. Hawaiian method of computation. The Hawaiian Spectator 2 (1): 91-94.

Clark, Ross, 2011. On the margins of Pacific linguistics: P.A. Lanyon-Orgill. Language and History 54 (2): 164-77.

Codrington, R.H., 1885. The Melanesian Languages. Oxford: Clarendon Press.

Comrie, Bernard, 2011. Typology of Numeral Systems. Leipzig: Max Planck Institute. https://mpi-lingweb.shh.mpg.de/numeral/TypNumCuhk_11ho.doc

Conant, Levi L., 1896. The Number Concept: Its Origin and Development. New York: Macmillan and Co.

Craik, George Lillie, 1830. The New Zealanders. Boston: Wells and Lilly.

Deighton, S., 1889. A Moriori Vocabulary. Letter from S. Deighton, Esq., R.M., Chatham Islands, Forwarding the First Portion Of. Appendix to the Journals of the House of Representatives, 1889 Session I, G.-5. National Library of New Zealand. Retrieved from https://atojs.natlib.govt.nz/cgi-bin/ atojs?a=d\&d=AJHR1889-I.2.2.5.6\&e=-------10--1------0--

Döhler, Christian, 2018. A Grammar of Komnzo. Studies in Diversity Linguistics 22. Berlin: Language Science Press.

d'Urville, Jules Dumont, Jean Baptiste Bory de Saint-Vincent and Alexandre Brongniart, 1829. Voyage Autour du Monde, Exécuté par Ordre du Roi, sur la Corvette de Sa Majesté, la Coquille, Pendant les Années 1822, 1823, 1824 et 1825. Botanique. Paris: Arthus Bertrand.

Dryander, Jonas, 1800. Catalogus Bibliotheca Historico-Naturalis Josephi Banks. Tomus V. Supplementum et Index Auctorum. London: Bulmer et Soc. 
Duperrey, Louis Isidore, 1825. Notice sur l'ensemble du voyage autour du monde de la Corvette du Roi la Coquille, commandée par M. Duperrey, lieutenant de vaisseau. In L.-M. Bajot (ed.), Annales Maritimes et Coloniales, II. ${ }^{e}$ Partie. Paris: L'imprimerie Royale, pp. 429-38.

-1826. Voyage Autour du Monde, Exécuté par Ordre du Roi, sur la Corvette de Sa Majesté, la Coquille, Pendant les Années 1822, 1823, 1824, et 1825. Paris: Arthus Bertrand.

-1828. Voyage Autour du Monde sur la Corvette la Coquille, Pendant les Années 1822-1825 (6 vols). Paris: Arthus Bertrand.

-1829. Tableaux des routes parcourues par la corvette de Sa Majesté, la Coquille, et des observations météorologiques faites à bord du bâtiment, pendant les années 1822, 1823, 1824 et 1825. In Voyage Autour du Monde, Exécuté par Ordre du Roi, sur la Corvette de Sa Majesté, la Coquille, Pendant les Années 1822, 1823, 1824 et 1825. Hydrographie et Physique. Paris: Arthus Bertrand, pp. 6-133.

Durrad, W.J., 1913. A Tikopia vocabulary (continued). Journal of the Polynesian Society 22 (87): 141-48.

Ellis, William, 1826. Narrative of a Tour through Hawaii, or Owhyhee; with Observations on the Natural History of the Sandwich Islands, and Remarks on the Manners, Customs, Traditions, History, and Language of their Inhabitants. London: H. Fisher, Son, and P. Jackson.

Evans, Nicholas, 2009. Two pus one makes thirteen: Senary numerals in the MoreheadMaro region. Linguistic Typology 13 (2): 321-35.

Eyriaud des Vergnes, P.-E., 1877. L'archipel des Îles Marquises. Paris: BergerLevrault et cie.

Fedorova, Irina K., 1993. The Rapanui language as a source of ethnohistorical information. Rongorongo Studies 3 (2): 52-60.

Findlay, Alexander G., 1851. A Directory for the Navigation of the Pacific Ocean; with Descriptions of Its Coasts, Islands, Etc., from the Strait of Magalhaens to the Arctic Sea, and Those of Asia and Australia. Part II: The Islands, Etc., of the Pacific Ocean. London: R.H. Laurie.

Fink, Karl, 1890. Kurzer Abriss Einer Geschichte der Elementar-Mathematik mit Hinweisen auf die Sich Anschliessenden Höheren Gebiete. Tübingen: H. Laupp'schen Buchhandlung.

Geraghty, Paul, 1983. Review, Lanyon-Orgill, Peter A.: Captain Cook's South Sea Island Vocabularies. London, Peter Lanyon-Orgill, 1979. Journal of the Polynesian Society 92 (4): 554-59.

González de Haedo, Don Felipe, 1770. The Voyage of Captain Don Felipe Gonzalez in the Ship of the Line San Lorenzo, with the Frigate Santa Rosalia in Company, to Easter Island in 1770-1771. Transcribed, translated and edited by B.G. Corney. Cambridge: Hakluyt Society.

Grabowsky, F., 1889. Aus Allen Erdtheilen. In F.K.E. Deckert (ed.), Globus. Illustrierte Zeitschrift für Länder- Und Völkerkunde mit Besonderer Berücksichtigung der Ethnologie, der Kulturberhältnisse und des Welthandels. Vol. LV(6). Braunschweig: Friedrich Vieweg und Sohn, pp. 94-96.

Günther, Siegmund, 1888. Ueber zahlbegriff, zahlschreibung und rechenkunst im lichte der völkerkunde. In W. von Gumbel et al. (eds), Verhandlungen der Münchener Anthropologischen Gesellschaft. Vol. 9. München: Friedrich Bassermann, pp. 1-2. 
Hale, Horatio, 1846. United States Exploring Expedition. During the Years 1838, 1839, 1840, 1841, 1842. Under the Command of Charles Wilkes, U.S.N. Vol. IV, Ethnography and Philology. Philadelphia, PA: C. Sherman.

Hammarström, Harald, 2010. Rarities in numeral systems. In J. Wohlgemuth and M. Cysouw (eds), Rethinking Universals: How Rarities Affect Linguistic Theory. Berlin: Walter de Gruyter, pp. 11-59.

Handy, Edward S.C., 1923. The Native Culture in the Marquesas. Honolulu: Bernice P. Bishop Museum.

Henrici, Peter, 1964. Elements of Numerical Analysis. New York: John Wiley and Sons. Hiroa, Te Rangi, 1938. Ethnology of Mangareva. Honolulu: Bernice P. Bishop Museum. Hongi, Hare, 1909. Maori numeration: Being a reply to Mr. Elsdon Best's paper on "Maori numeration" in Trans. N.Z. Inst., Vol. XXXIX. Transactions of the New Zealand Institute XLII: 625-40.

Janeau, Vincent-Ferrier, 1908. Essai de Grammaire de la Langue des Iles Gambier ou Mangaréva par les Missionnaires Catholiques de Cet Archipel, Membres de la Congrégation des Sacrés-Cours de Picpus. Braine-le-Comte, Belgium: Imprimerie Zech et Fils.

Kahaner, David K., 1993. International conference on scientific computation and differential equations, Auckland, New Zealand. Scientific Information Bulletin 18 (2): 61-67.

Keate, George, 1788. A vocabulary of the Pelew language. In An Account of the Pelew Islands, Situated in the Western Part of the Pacific Ocean. Composed from the Journals and Communications of Captain Henry Wilson and Some of His Officers, Who, in August 1783, Were There Shipwrecked, in the Antelope, a Packet Belonging to the Hon. East India Company. Dublin: Luke White, pp. 365-78.

Labillardière, Jacques de, 1799. Relation du Voyage à la Recherche de La Pérouse, Fait par Ordre de l'Assemblée Constituante, Pendant les Années 1791, 1792, et Pendant

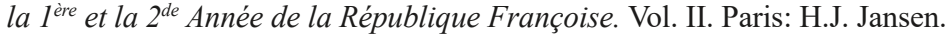

Lanyon-Orgill, Peter A., 1979. Captain Cook's South Sea Island Vocabularies. London: Peter Lanyon-Orgill.

Lee, Samuel, 1820. A Grammar and Vocabulary of the Language of New Zealand. London: Church Missionary Society.

Lemaitre, Yves, 2004. Austral (Rurutu), French Polynesia. Numeral Systems of the World's Languages. Max Planck Institute. https://mpi-lingweb.shh.mpg.de/ numeral/Austral-Rurutu.htm

Lesson, René-Primevère, 1825a. Arrivée à Marseille de la Corvette du Roi la Coquille, de retour de son voyage autour du monde. Deux lettres écrites l'une de la Nouvelle-Hollande et l'autre de Bourbon, contenant des détails sur son itinéraire, ses travaux et ses découvertes. In L.-M. Bajot (ed.), Annales Maritimes et Coloniales, II. ${ }^{e}$ Partie. Paris: L'imprimerie Royale, pp. 321-35.

- 1825b. Notice sur l'ile de Oualan ou Strong. Paris: Imprimerie de Gotschy.

- 1825c. Notice sur l'île de Rotouma, située dans le grand-océan austral. In J.-B. B. Eyriès and C. Malte-Brun (eds), Nouvelles Annales des Voyages, de la Géographie et de l'Histoire. Vol. XXVII. Paris: Librairie de Gide Fils, pp. 1-47. 1826. Considérations générales sur les îles du grand-océan et sur les variétés de l'espèce humaine qui les habitent. In Voyage Autour du Monde, Exécuté par Ordre du Roi, sur la Corvette de Sa Majesté, la Coquille, Pendant les Années 1822-1825. Zoologie, Vol. 1. Paris: Arthus Bertrand, pp. 1-30. 
1827a. Grammaire de la langue Madécasse, par feu M. Chapelier, naturaliste du gouvernement, à Madagascar. In L.-M. Bajot (ed.), Annales Maritimes et Coloniales, 2. ${ }^{e}$ Partie. Paris: L'imprimerie Royale, pp. 90-121.

1827b. Mœurs et usages des habitans de la Nouvelle-Zélande. In L.-M. Bajot (ed.), Annales Maritimes et Coloniales, 2. ${ }^{e}$ Partie. — Tome 2. Paris: L'imprimerie Royale, pp. 62-75.

1828a. Histoire Naturelle Générale et Particulière des Mammifères et des Oiseaux Découverts Depuis 1788 Jusqu'à Nos Jours. Races Humaines. Paris: Baudouin Frères.

—1828b. Mémoire sur les habitans de la Nouvelle-Zélande. In Journal des Voyages, Découvertes et Navigations Modernes, ou Archives Géographiques du XIXe Siècle, Rédigé par une Société de Géographes, de Voyageurs et de Littérateurs Français et Etrangers. Vol. XL. Paris: Bureau du Journal, pp. 38-57.

1829a. Histoire Naturelle Générale et Particulière des Mammifères et des Oiseaux Découverts Depuis 1788 Jusqu'à Nos Jours. Races Humaines, Orangs et Gibbons. Paris: Baudouin Frères.

1829b. Mémoire sur les diverses races humaines répandues sur les Îles du grand-océan, et considérées sous les divers rapports physiologiques, naturels et moraux. In Voyage Médical Autour du Monde, Exécuté sur la Corvette du Roi la Coquille, Commandée par M. L. I. Duperrey, Pendant les Années 1822, 1823, 1824 et 1825. Paris: Roret, pp. 153-230.

-1829c. Notice sur Shongi, chef d'une tribu de la Nouvelle-Zélande. In L.-M. Bajot (ed.), Annales Maritimes et Coloniales, II. ${ }^{e}$ Partie. Paris: L'imprimerie Royale, pp. 461-66.

-1830. Voyage Autour du Monde, Exécuté par Ordre du Roi, sur la Corvette de Sa Majesté, la Coquille, Pendant les Années 1822, 1823, 1824 et 1825. Zoologie, Vol. 2. Paris: Arthus Bertrand.

Lesson, René-Primevère and Prosper Garnot, 1826. Voyage Autour du Monde, Exécuté par Ordre du Roi, sur la Corvette de Sa Majesté, la Coquille, Pendant les Années 1822-1825: Zoologie, Vol. 1. Paris: Arthus Bertrand.

Martin, John, 1818. An Account of the Natives of the Tonga Islands, in the South Pacific Ocean. With an Original Grammar and Vocabulary of Their Language. Compiled and Arranged from the Extensive Communications of Mr. William Mariner, Several Years Resident in Those Islands. Vol. II. London: John Murray. Maunsell, Robert, 1842. A Grammar of the New Zealand Language. Auckland: J. Moore. -1862. A Grammar of the New Zealand Language, 2nd ed. Auckland: W.C. Wilson. Nishimoto, Noa, 2015. Austral (Rurutu), French Polynesia. Numeral Systems of the World's Languages. Max Planck Institute. https://mpi-lingweb.shh.mpg.de/ numeral/Austral-Rurutu.htm

Overmann, Karenleigh A., 2018a. Constructing a concept of number. Journal of Numerical Cognition 4 (2): 464-93.

2018b. Updating the "abstract-concrete" distinction in Ancient Near Eastern numbers. Cuneiform Digital Library Journal 1: 1-22.

2019. The Material Origin of Numbers: Insights from the Archaeology of the Ancient Near East. Gorgias Studies in the Ancient Near East 14. Piscataway, NJ: Gorgias Press. 
Peacock, George, 1845. Arithmetic. In E. Smedley, H.J. Rose and H.J. Rose (eds), Encyclopcedia Metropolitana; or Universal Dictionary of Knowledge, on an Original Plan: Comprising the Twofold Advantage of a Philosophical and an Alphabetical Arrangement, with Appropriate Engravings. Vol. 1, Pure Sciences. London: B. Fellowes, pp. 368-523.

Pott, August Friedrich, 1847. Die Quinare und Vigesimale Zählmethode bei Völkern Aller Welttheile: Nebst Ausführlicheren Bemerkungen Über die Zahlwörter Indogermanischen Stammes und Einem Anhange Über Fingernamen. Halle: C.A. Schwetschke und Sohn.

Rallet, Louis, 1953. Un naturaliste saintongeais: René-Primevère Lesson (1794-1849). Annales de la Société des Sciences Naturelles de la Charente-Maritime III (8): 77-131.

Reinach, Salomon, 1890. Review, Dr Siegmund Günther. Les systèmes de numération à la lumière de l'ethnographie (beilræge zur anthropologie und urgeschichte Bayerns, Munich, Bassermann, 1890). In E. Cartailhac, E.T. Hamy and P. Topinard (eds), L'anthropologie, Vol. 1. Paris: G. Masson, pp. 614-15.

Reuleaux, Franz, 1885. Ein ausflug nach Neuseeland. In Westermanns Illustrierte Deutsche Monatshefte. Vol. 57. Braunschweig: George Westermann, pp. 270-92.

Rooryck, Johan, Alberto Tonda, Jairo Saw and Pierre Pica, 2017. Mundurucu number words as a window on short-term memory. Poster presented at the discussion meeting Origins of Numerical Abilities: The Future, Royal Society of London, UK. https://halshs.archives-ouvertes.fr/halshs-01497577

Rotman, Brian, 2000. Mathematics as Sign: Writing, Imagining, Counting. Stanford: Stanford University Press.

Savage, John, 1807. Some Account of New Zealand; Particularly the Bay of Islands and Surrounding Country; with a Description of the Religion and Government, Language, Arts, Manufactures, Manners, and Customs of the Natives, \&c. \&c. London: John Murray.

Schlimm, Dirk, 2018. Numbers through numerals: The constitutive role of external representations. In Sorin Bangu (ed.), Naturalizing Logico-Mathematical Knowledge: Approaches from Psychology and Cognitive Science. New York: Routledge, pp. 195-217.

Schubert, H., 1888. Das zählen. In G. Neumayer (ed.), Anleitung zu Wissenschaftlichen Beobachtungen auf Reisen. Vol. 2. Berlin: Robert Oppenheim, pp. 288-94.

Tee, Garry J., 1987. Mathematical science in New Zealand. Gaṇita Bhāratī 9 (1-4): $1-9$.

1988. Mathematics in the Pacific Basin. British Journal for the History of Science 21 (4): 401-17.

Tylor, Edward B., 1871. Primitive Culture: Researches into the Development of Mythology, Philosophy, Religion, Art, and Custom. Vol. 1. London: John Murray.

von Chamisso, Adelbert, 1821a. Remarks and opinions of the naturalist of the expedition. In A Voyage of Discovery, into the South Sea and Beering 's Straits, for the Purpose of Exploring a North-East Passage, Undertaken in the Years 1815-1818, at the Expense of His Highness the Chancellor of the Empire, Count Romanzoff, in the Ship Rurick. Vol. II. London: Longman, Hurst, Rees, Orme, and Brown, pp. 350-410. 
$1821 \mathrm{~b}$. Vocabulary of the dialects Chamori, (Mariana Islands), and of Eap, Ulea, and Radack. In A Voyage of Discovery, into the South Sea and Beering 's Straits, for the Purpose of Exploring a North-East Passage, Undertaken in the Years 1815-1818, at the Expense of His Highness the Chancellor of the Empire, Count Romanzoff, in the Ship Rurick. Vol. II. London: Longman, Hurst, Rees, Orme, and Brown, pp. 411-33.

1821c. Corrections and remarks. In A Voyage of Discovery, into the South Sea and Beering's Straits, for the Purpose of Exploring a North-East Passage, Undertaken in the Years 1815-1818, at the Expense of His Highness the Chancellor of the Empire, Count Romanzoff, in the Ship Rurick. Vol. III. London: Longman, Hurst, Rees, Orme, and Brown, pp. 439-42.

1825. Du grand océan, de ses îles et de ses côtes. In L.-M. Bajot (ed.), Annales Maritimes et Coloniales, II. ${ }^{e}$ Partie - Tome 2; Traduit sur l'édition anglaise par R. P. Lesson, Médecin de la Corvette la Coquille, Pharmacien de la marine, Membre de plusieurs sociétés savantes, \&c. Paris: L'imprimerie Royale, pp. 1-41.

von Humboldt, Wilhelm, 1839. Über die Kawi-Sprache aus der Insel Java, Nebst Einer Einleitung Über die Verschiedenheit des Menschlichen Sprachbaues und Ihren Einsluss aus die Geistige Entwickelung des Menschengeschlechts. Band III, Südsee-Sprachen, als Östlicher Zweig des Malayischen. Berlin: F. Dümmler.

von Zach, Franz Xaver, 1826. Correspondance astronomique, géographique, hydrographique et statistique. In E. Saigey (ed.), Bulletin des Sciences Mathématiques, Astronomiques, Physiques et Chimiques, Vol. 5, $1^{\text {ère }}$ Section. Paris: Bureau du Bulletin, pp. 120-23.

Williams, Francis E., 1936. Papuans of the Trans-Fly. Oxford: Clarendon Press.

Williams, William, 1844. A Dictionary of the New-Zealand Language, and a Concise Grammar; to Which Are Added a Selection of Colloquial Sentences. Paihia: The Press of the Church Mission Society.

-1852. A Dictionary of the New Zealand Language, and a Concise Grammar; to Which Are Added a Selection of Colloquial Sentences. 2nd ed. London: Williams and Norgate.

Williams, William Leonard, 1871. A Dictionary of the New Zealand Language; to Which Is Added a Selection of Colloquial Sentences. 3rd ed. London: Williams and Norgate.

1892. A Dictionary of the New Zealand Language. 4th ed. Auckland: Upton and $\mathrm{Co}$.

\section{AUTHOR CONTACT DETAILS}

Karenleigh A. Overmann, Department of Psychosocial Science, University of Bergen, Christies Gate 12, 4, Etasje, 5015 Bergen, Norway; and Center for Cognitive Archaeology, Department of Anthropology, University of Colorado at Colorado Springs, 1420 Austin Bluffs Pkwy, Colorado Springs, Colorado 80918, USA. Email: karenleigh.overmann@ keble.oxon.org 